\title{
Antimicrobial Potential of Usnea longissima Ach. Lichen Against Human Pathogens
}

\section{Usnea longissima Ach. Likeninin İnsan Patojenlerine Karşı Antimikrobiyal Potansiyeli}

\author{
Kadir KINALIOĞLU ${ }^{1, a}$, Sinem AYDIN*1,b, Bahar BÍLGİN SÖKMEN ${ }^{2, c}$ \\ ${ }^{I}$ Giresun University, Faculty of Science and Arts, Department of Biology, Giresun University, 28100, Giresun \\ ${ }^{2}$ Giresun University, Faculty of Science and Arts, Department of Chemistry, Giresun University, 28100, Giresun
}

• Geliş tarihi / Received: 18.02.2019 • • Düzeltilerek geliş tarihi / Received in revised form: 05.07.2019 Kabul tarihi / Accepted: 12.07.2019

\begin{abstract}
Lichens are a symbiotic associations between a fungus and algae and/or cyanobacteria. Lichens use as food and dye source, air pollution indicator, medicinal and decoration. In this study, antimicrobial activity of ethyl acetate and ethanol extracts of Usnea longissima Ach. lichen was searched by disc diffusion method. While inhibition zones range from $14.5 \mathrm{~mm}$ to $24.5 \mathrm{~mm}$ for bacteria, inhibition zones range from $10 \mathrm{~mm}$ to $32 \mathrm{~mm}$ for fungi. Lichen extracts exhibited higher activity than gentamicin and tetracycline but they showed similar activity to nystatin. The MIC values of the extracts varied between 2-117 $\mu \mathrm{g} / \mathrm{mL}$ against bacteria; while the MIC values of the extracts varied between 4-59 $\mu \mathrm{g} / \mathrm{mL}$ against fungi. According to the obtained results, it could be said that $U$. longissima might be an alternative to synthetic antimicrobial agents.
\end{abstract}

Keywords: Antimicrobial activity, Lichen, Microorganism

$\ddot{O} z$

Likenler bir mantar ve bir alg velya da siyanobakteri arasindaki simbiyotik birlikteliklerdir. Likenler besin ve boya kaynağı, hava kirliliği indikatörü, tıbbi ve dekorasyon amaçlı kullanılmaktadır. Bu çalışmada, Usnea longissima Ach. likeninin etanol ve etil asetat ekstraktlarının antimikrobiyal aktiviteleri disk difüzyon metodu ile araştırldd. Bakteriler için inhibisyon zonları $14.5 \mathrm{~mm}$ ve $24.5 \mathrm{~mm}$ arasında değişirken; mantarlar için $10 \mathrm{~mm}$ ve $32 \mathrm{~mm}$ arasında değişmektedir. Liken ekstraktları gentamisin ve tetrasiklinden daha yüksek ve nistatine benzer aktivite göstermiştir. Ekstraktların bakterilere karşı MiK değerleri 2-117 $\mu \mathrm{g} / \mathrm{mL}$ arasında değişirken; mantarlara karşı MiK değerleri 4-59 $\mu \mathrm{g} / \mathrm{mL}$ arasında değişmektedir. Elde edilen sonuçlara göre, U. longissima'nın sentetik antimikrobiyal ajanlara alternatif olabileceği söylenebilir.

Anahtar kelimeler: Antimikrobiyal aktivite, Liken, Mikroorganizma

\footnotetext{
*b Sinem AYDIN; sinem.aydin@giresun.edu.tr; Tel: (0454) 31040 41; orcid.org/0000-0002-0484-7191

${ }^{a}$ orcid.org/0000-0001-6564-7778 $\quad{ }^{c}$ orcid.org/0000-0003-3904-8178
} 


\section{Intrdouction}

Antibiotics provide the first therapy of microbial infections. When the discovery of these medicines as chemotherapeutic agents it was thought that this would guide to wipe out spreading infectious diseases. Recently, most of the microorganisms gained resistance current antibiotics. Therefore, there is a perpetual and urgent requirement to find brand antimicrobial compounds which possess various chemical structures and new mechanisms of action (Amenu, 2014).

Medicinal plants symbolize natural alternatives to synthetic antimicrobial agents. Plants are utilized medicinally in worldwide. A wide range of medicinal plant is utilized for extraction as raw drugs. Moreover, medicinal plants are trusted to be significant source of brand chemical substances with potential therapeutic actions. The secondary compounds of plants might be utilized as intermediates for the production of brand drugs (Chandra, 2013).

Lichen is a symbiotic association between a fungus and algae and/or cyanobacteria. They are used as food and dye source, air pollution indicator, medicinal and decoration. Usnea longissima is one of the medical lichens used in the treatment of bone fractures and sprains, in the treatment of leg injuries and ulcers (Atalay et al., 2011). Moreover, $U$. longissima is used as an expectorant, wound dressing material and nose bleed in various parts of the world (Ağar et al., 2011). U. longissima is currently used for the treatment of tuberculous lymphadenitis (Hobbs, 1990). U. longissima has antiulcerogenic effect on stomach ulcer model induced by indomethazine
(Halici et al., 2005). U. longissima was used as an expectorant and a powder application to treat external ulcers in the name "Sun-Lo" by the Chinese. Moreover, it is also a major ingredient of Chinese medicine. In the Bolivian Andes, $U$. longissima is used as a medicine to heal cough and hoarseness. It has been used for stimulating menstruation or induce abortion by Unani medicine (Prateeksha et al., 2016).

It was aimed to investigate antimicrobial potential of ethyl acetate and ethanol extracts of $U$. longissima against Salmonella enterica serovar typhimurium ATCC 14028, Proteus vulgaris FMC 1, Enterobacter aerogenes CCM 2531, Yersinia pseudotuberculosis (laboratory isolate), Escherichia coli ATCC 35218, Gordonia rubripertincta (laboratory isolate), Staphylococcus aureus ATCC 25923, Bacillus subtilis IMG 22, Enterococcus faecalis ATCC 29212, Bacillus cereus 702 ROMA, Saccharomyces cerevisiae, Candida tropicalis ATCC 13803 and Candida albicans FMC 17.

\section{Material and Methods}

\subsection{Collection and Identification of Lichen Material}

Lichen samples (Figure 1) were collected from the trunks of coniferous tree from Dereli district in the province of Giresun in 2017. Collected lichen specimens was dried at room temperature and identified as Usnea longissima Ach. according to the Brodo et al. (2001). The voucher samples deposited in the herbarium of the Biology Department, Faculty of Science and Arts, Giresun University, Giresun, Turkey).

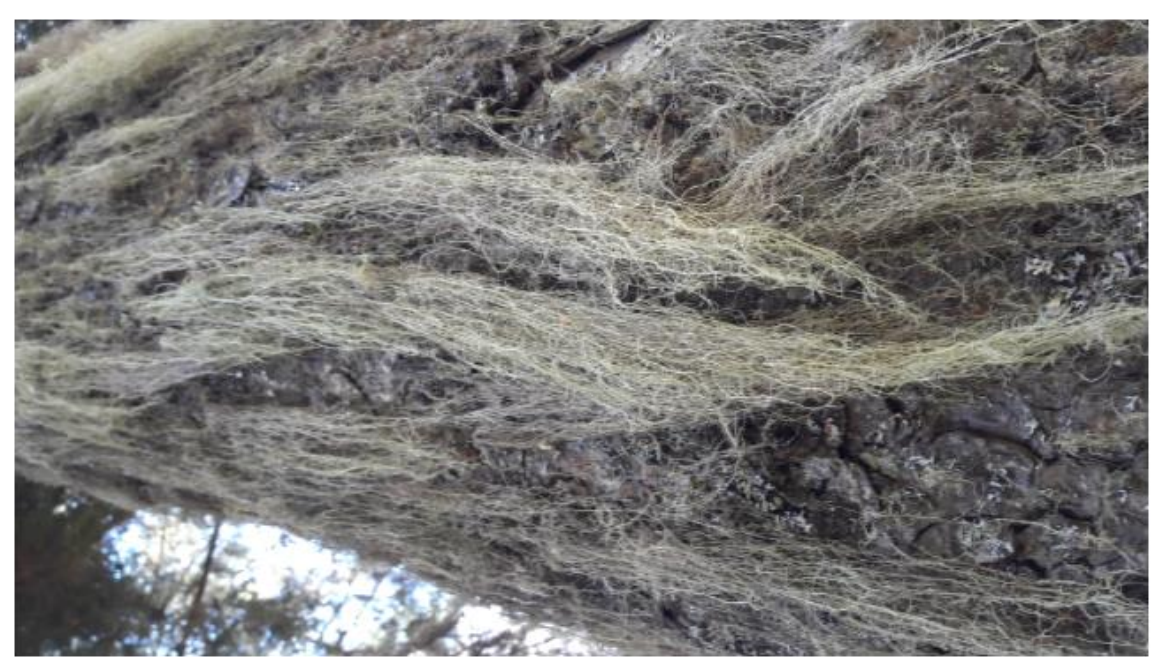

Figure 1. Usnea longissima Ach. 


\subsection{Lichen Extraction}

Soxhlet apparatus was used to obtain of lichen extracts. $25 \mathrm{~g}$ of the powdered sample was extracted with $250 \mathrm{~mL}$ ethyl acetate and ethanol solvents, separately. The extraction process followed by filtration with Whatman filter paper no 1 . Then, the filtered extract concentrated in vacuum at $40{ }^{\circ} \mathrm{C}$ using a rotary evaporator (Kumar et al., 2012).

\subsection{Microorganisms}

5 Gram (+), 5 Gram (-) bacteria and 3 fungi were used in this study. Salmonella enterica serovar typhimurium ATCC 14028, Staphylococcus aureus ATCC 25923 and Saccharomyces cerevisiae were provided by Giresun Province Control Laboratory. Proteus vulgaris FMC 1, Enterobacter aerogenes CCM 2531, Bacillus subtilis IMG 22, Candida tropicalis ATCC 13803 and Candida albicans FMC 17 were provided by Frrat University. Escherichia coli ATCC 35218 was provided by Giresun University. Yersinia pseudotuberculosis (laboratory isolate) and Gordonia rubripertincta (laboratory isolate) were provided by Yeditepe University. Enterococcus faecalis ATCC 29212 and Bacillus cereus 702 ROMA were provided by Recep Tayyip Erdoğan University.

\subsection{Antimicrobial Activity}

The antimicrobial potential of the extracts of $U$. longissima was identified by disc diffusion assay. Each lichen extract was dissolved in dimethyl sulfoxide (DMSO) $(2.5 \%$ concentration) at 30 $\mathrm{mg} / \mathrm{mL}$ concentration. Dissolved extracts were sterilized through $0.45 \mu \mathrm{m}$ pore sized filter. Gentamicin and tetracycline were used as standard antimicrobial agent. The turbidity of bacterial suspensions was adjusted $0.5 \mathrm{Mc}$ Farland standards $\left(10^{8} \mathrm{CFU} / \mathrm{mL}\right)$, then, the bacterial suspension inoculated into MHA plates and allowed to dry. Discs (5 mm diameter) were put onto the inoculated agar. $25 \mu \mathrm{L}$ ethyl acetate extract of $U$. longissima, $25 \mu \mathrm{L}$ ethanol extract of $U$. longissima and $25 \mu \mathrm{L}$ DMSO were added to discs, separately. The inoculated plates were left in refrigerator for one hour then plates were incubated at $37^{\circ} \mathrm{C}$ overnight. Diameters of zones were measured. The sensitivity of the microorganisms to the studied lichens was revealed by measuring the inhibitory zones size on the agar surface around the discs (Murray et al., 1995; Sarić et al., 2009).
Antifungal activity was determined by disc diffusion method with Sabaroud Dextrose Agar (SDA) and Sabaroud Dextrose Broth (SDB). The procedure which was used in bacteria was used to determine antifungal activity except for the turbidity of fungal suspensions were adjusted 0.5 Mc Farland standard $\left(10^{7} \mathrm{CFU} / \mathrm{mL}\right)$ (Ertürk, 2006). Nystatin was used as standard antifungal agent. Discs were put (5 $\mathrm{mm}$ diameter) onto the agar and $25 \mu \mathrm{L}$ ethyl acetate extract of $U$. longissima, $25 \mu \mathrm{L}$ ethanol extract of $U$. longissima and $25 \mu \mathrm{L}$ DMSO were added to discs, separetely. Plates were incubated at $35{ }^{\circ} \mathrm{C}$ for 48 h. Diameter of inhibition zones were measured in millimeters (Ünal et al., 2008). All the antimicrobial tests were carried twice.

The macrobroth dilution method was used to determine MIC values. Firstly, the 96 well plates were prepared by dispensing into each well $95 \mu \mathrm{L}$ of Mueller Hinton Broth and $5 \mu \mathrm{L}$ of the inoculums. $100 \mu \mathrm{L}$ (prepared at $30 \mathrm{mg} / \mathrm{mL}$ concentration) ethyl acetate and ethanol extracts of $U$. longissima initially prepared at the concentration of $1 \mathrm{mg} \mathrm{mL}^{-1}$ was added into the first wells. Then, $100 \mu \mathrm{L}$ from their serial dilutions were added into seven consecutive wells. This 96 well plate was incubated at $37{ }^{\circ} \mathrm{C}$ for bacteria overnight and $35{ }^{\circ} \mathrm{C}$ for $48 \mathrm{~h}$ for fungi. The MIC was expressed as the lowest concentration of the test compounds to inhibit the growth of microorganisms (Güllüce et al., 2004).

\section{Results and Discussion}

Plants are advantageous because of containing various compounds with healthy effects. Both essential oils of these plants and their extracts are useful in the treatment of many infectious diseases in the respiratory and gastrointestinal system, urinary tract. Because of the negative effects of antibiotics, increased resistance of antibiotics and the high production cost of generation of chemical compounds, drug companies are searching for brand alternatives. Some scientists stated that medicinal plants might be utilized in pharmaceutical industry. Rising awareness of people towards natural food and natural therapies seems to an alternative (Keskin et al., 2010).

The current study was performed to gain preliminary knowledge on the antimicrobial activity of $U$. longissima. Antimicrobial activity of the lichen extracts were determined by KirbyBauer technique of disc diffusion method. Minimum inhibitory concentration was taken out by Broth micro dilution method according to the 
NCCLS guidelines. Antimicrobial activity of the tested lichen extracts was demonstrated in Table 1. Both ethanol and ethyl acetate extracts of $U$. longissima exhibited no activity against $Y$. pseudotuberculosis, E. coli and S. enterica serovar typhimurium. The extracts showed higher effect than the commercial antibiotic tetramycine and gentamicin, although extracts showed similar activity with standard antifungal agent nystatin.
While the inhibition zones of the test bacteria were found ranged from $14.5 \mathrm{~mm}$ to $24.5 \mathrm{~mm}$, the inhibition zones were detected ranged from 10 $\mathrm{mm}$ to $32 \mathrm{~mm}$ for fungi. Generally, gram (-) bacteria were more resistant than gram (+) bacteria against the lichen extracts. This situation might be arisen from the difference of cell wall in gram (+) and gram (-) bacteria.

Table 1. Inhibition zones of the tested extracts $(\mathrm{mm})$

\begin{tabular}{|c|c|c|c|c|c|c|}
\hline Microorganism & $\mathbf{E U}$ & EAU & DMSO & Tetra & Genta & Nys \\
\hline S. aureus & 14.5 & 16 & $\mathrm{NA}$ & 17.5 & 19 & NA \\
\hline B. subtilis & 23 & 21 & NA & 13 & 16 & NA \\
\hline Y. pseudotuberculosis & NA & NA & NA & NA & 19 & NA \\
\hline E. aerogenes & 21 & 22.5 & NA & 9.5 & 15 & NA \\
\hline B. cereus & 25 & 21.5 & NA & 13 & 17.5 & NA \\
\hline P. vulgaris & 23.5 & 24.5 & NA & 12.5 & 17 & NA \\
\hline E. faecalis & 21 & 20.5 & NA & NA & 16.5 & NA \\
\hline E. coli & NA & NA & NA & 14.5 & 17.5 & NA \\
\hline $\begin{array}{l}\text { S. enterica serovar } \\
\text { typhimurium }\end{array}$ & NA & NA & NA & 14 & 17 & NA \\
\hline G. rubripertincta & 17 & 18 & NA & 16 & 22 & NA \\
\hline C. tropicalis & 27 & 25 & NA & NA & NA & 30 \\
\hline C. albicans & 32 & 29.5 & NA & NA & NA & 30 \\
\hline S. cerevisiae & 13 & 10 & NA & NA & NA & 13 \\
\hline
\end{tabular}

EU: Ethanol extract of $U$. longissima; EAU: Ethyl acetate extract of $U$. longissima; NA: No Activity; Tetra: Tetracycline (10 $\mu \mathrm{g} / \mathrm{disc})$; Gen: Gentamicin $(10 \mu \mathrm{g} / \mathrm{disc})$; Nys: Nystatin $(100 \mu \mathrm{g} / \mathrm{disc})$

Table 2 represents MIC values of the test extracts. The MIC values of the extract varied between 2$117 \mu \mathrm{g} / \mathrm{mL}$ against bacteria; while The MIC values of the extract varied between $4-59 \mu \mathrm{g} / \mathrm{mL}$ against fungi. Lichen extracts exhibited higher activity against fungi than bacteria.

Table 2. Results of MIC values of the extracts $(\mu \mathrm{g} / \mathrm{ml})$

\begin{tabular}{lcclcc}
\hline Microorganism & EU & EAU & Microorganism & EU & EAU \\
\hline S. aureus & 59 & 117 & E. faecalis & 29 & 59 \\
B. subtilis & 2 & 2 & G. rubripertincta & 59 & 117 \\
E. aerogenes & 7 & 14 & C. tropicalis & 5 & 4 \\
B. cereus & 14 & 29 & C. albicans & 59 & 7 \\
$P$. vulgaris & 14 & 7 & S. cerevisiae & 59 & 29 \\
\hline
\end{tabular}

Similar reports on antimicrobial effects of $U$. longissima are available in the literatüre. For example, Maulidiyah et al. (2016) investigated chloroform fraction of $U$. longissima and it concluded that there was activity against $E$. coli, $S$. aureus and S. typhi. In contrast of this study, we found antimicrobial activity of ethanol and ethyl acetate extracts of $U$. longissima against $E$. coli and $S$. typhimurium. This difference could be related with collecting lichen samples from different locations and using different extract amounts and types. Kamal et al. (2015) searched antibacterial activity of ethanol and methanol extracts of Usnea sp. which collected from India against $S$. aureus, $P$. aeruginosa, $K$. pneumoniae,
S. typhi and E. coli. They found activity in both ethanol and methanol extracts of Usnea sp. against $S$. aureus, E. coli and S. thyphi. However, in our study we found no activity against $E$. coli and $S$. enterica serovar typhimurium but we detected activity against $S$. aureus. This situation might be arisen from collecting lichens in different locations. Rauf et al. (2011) stated that hydroalcoholic and ethanolic extracts of $U$. longissima possess significant antibacterial property towards $S$. aureus, B. cereus, E. coli and $P$. vulgaris. In our survey, we also found activity for $S$. aureus, B. cereus and P. vulgaris; but no activity against $E$. coli. Dandapat and Paul (2015) investigated antimicrobial activity of Usnea 
longissima against E. coli, S. aureus and S. typhi. Siddiqi et al. (2018) searched antimicrobial activity of silver nanoparticles using aqueousethanolic extract of Usnea longissima. Thippeswamy et al. (2011) revealed that ethanolic extract of $U$. longissima had activity against $S$. aureus, Pseudomonas aeruginosa, Klebsiella pneumoniae, Shigella dysenteriae, Salmonella typhimurium, E. coli, Trichoderma viridi and $C$. albicans. Cansaran et al. (2006) determined that acetone extract of $U$. longissima had activity against $B$. subtilis and $B$. megaterium but had no activity against $E$. coli, E. faecalis, $P$. mirabilis, $S$. aureus and $P$. aeruginosa. In contrast to this study, we found activity against $S$. aureus, $B$. subtilis and E. faecalis. In this study, we found no activity against E. coli. Koçer et al. (2014) searched antimicrobial activity of hydroxyphenylimino ligands and their metal complexes of usnic acid isolated from $U$. longissima. It was concluded that the ligands and their complexes of the ligands exhibited between $11 \mathrm{~mm}$ to $32 \mathrm{~mm}$ inhibition zones against test microorganisms. The power of antimicrobial action depends on extract type, concentration of used extract and the tested microorganisms (Srivastava et al., 2013).

\section{Conclusions}

The obtained results revealed that ethyl acetate and ethanol extracts of $U$. longissima possess important antimicrobial activity against the tested bacteria and fungi which have significance in human therapy, animal and plant diseases. Further studies about antimicrobial activity as well as the isolation of the metabolites from the $U$. longissima lichen are needed. Therefore, the antimicrobial effect of lichen tested might be explained with new and broad studies by utilizing various solvents for extraction.

\section{Acknowledgement}

This study was supported by Giresun University Scientific Project (Project No: FEN-BAPA140316-62).

\section{References}

Ağar, G., Aslan, A., Sarığlu, E.K., Alpsoy, L. and Çeker, S., 2011. Protective activity of the methanol extract of Usnea longissima against oxidative damage and genotoxicity caused by aflatoxin $\mathrm{B}_{1}$ in vitro. Turkish Journal of Medical Sciences, 41 (6), 1043-1049.
Amenu, D., 2014. Antimicrobial activity of medicinal plant extracts and their synergetic effect on some selected pathogens. American Journal of Ethnomedicine, 1(1), 18-29.

Atalay, F., Halıcı, M.B., Mavi, A., Çakır, A., Odabaşoğlu, F., Kazaz, C., Aslan, A. and Küfrevioğlu, Ö.İ., 2011. Antioxidant phenolics from Lobaria pulmonaria (L.) Hoffm. and Usnea longissima Ach. lichen species. Turkish Journal of Chemistry, 35, 647 - 661.

Brodo, I.M., Sharnoff, S. and Sharnoff, S., 2001. Lichens of North America: London, Yale University Press, 795p.

Cansaran, D., Kahya, D., Yurdakulol, E. and Atakol, O., 2006. Identification and quantification of usnic acid from the lichen Usnea species of Anatolia and antimicrobial activity. Zeitschrift für Naturforschung, 61c, 773-776.

Chandra, M., 2013. Antimicrobial activity of medicinal plants against human pathogenic bacteria. International Journal of Biotechnology and Bioengineering Research, 4(7), 653-658.

Dandapat, M. and Paul, S., 2019. Secondary metabolites from lichen Usnea longissima and its pharmacological relevance. Pharmacognosy Research, 11(2), 103-109.

Ertürk, Ö., 2006. Antibacterial and antifungal activity of ethanolic extracts from eleven spice plants. Biologia Bratislava, 61, 275-278.

Güllüce, M., Adıgüzel, A., Öğütçü, H., Şengül, M., Karaman, I. and Şahin, F., 2004. Antimicrobial effects of Quercus ilex L. extract. Phytotheraphy Research, 18, 208- 211.

Halici, M., Odabasoglu, F., Suleyman, H., Cakir, A., Aslan, A. and Bayir, Y., 2005. Effects of water extract of Usnea longissima on antioxidant enzyme activity and mucosal damage caused by indomethacin in rats. Phytomedicine, 12, 656662.

Hobbs, C. 1990. Usnea: The Herbal Antibiotic and Other Medicinal Lichens: California, Botanica Press, 20p.

Kamal, S., Manish, S., Savita, J. and Jasumati, 2015. Assessment of antibacterial activity of Usnea species of Shimla Hills. International Journal of Current Microbiology and Applied Sciences, 4(7), 413-425.

Keskin, D., Oskay, D. and Oskay, M., 2010. Antimicrobial activity of selected plant spices marketed in the West Anatolia. International Journal of Agriculture and Biology, 12, 916920. 
Koçer, S., Uruş, S., Çakır, A., Güllüce, M., Dığrak, M., Alan, Y., Aslan, A., Tümer, M., Karadayı, M., Kazaz, C. and Dal, H., 2014. The synthesis, characterization, Antimicrobial and antimutagenic activities of hydroxyphenylimino ligands and their metal complexes of usnic acid isolated from Usnea longissima. Dalton Transactions, 43, 6148-6164.

Kumar, S., Dhankhar, S., Arya, V.P., Yadav, S. and Yadav, J.P., 2012. Antimicrobial activity of Salvadora oleoides Decne. against some microorganisms. Journal of Medicinal Plants Research, 6 (14), 2754-2760.

Maulidiyah, I., Muntu, W. and Nurdin, M., 2016. Secondary metabolites identification from Usnea longissima Ach.: Bioactivity test of antibacterial. International Journal of Applied Chemistry, 12(3), 347-357.

Murray, P.R., Baron, E.J., Pfaller, M.A., Tenovar, F.C. and Yolke, R.H., 1995. Manual of Clinical Microbiology: Washington DC., ASM Press, 1482p.

Prateeksha, Paliya, B.S., Bajpai, R., Jadaun, V., Kumar, J., Kumar, S., Upreti, D.K., Singh, B.R., Nayaka, S., Joshi, Y. and Singh, B.N., 2016. The genus Usnea: a potent phytomedicine with multifarious ethnobotany, phytochemistry and pharmacology. RSC Advances, 6, 21672-21696.

Rauf, A., Latif, A., Rehman, R. and Afaq, S.H., 2011. In-vitro antibacterial screening of extracts of
Usnea longissima lichen. International Journal of Applied Biology and Pharmaceutical Technology, 2(2), 14-18.

Šarić, Ć.L., Ćabarkapa, S.I., Beljkaš, M.B., Mišan, Ć.A., Sakać, B.M. and Plavšiće, V.D., 2009. Antimicrobial activity of plant extracts from Serbia. Food Processing, Quality and Safety, 1(2), 1-5.

Siddiqi, K.S., Rashid, M., Rahman, A., Tajuddin, Husen, A. and Rehman, S., 2019. Biogenic fabrication and characterization of silver nanoparticles using aqueous ethanolic extract of lichen (Usnea longissima) and their antimicrobial activity. Biomaterials Research, $22,23-32$.

Srivastava, P., Upreti, D.K., Dhole, T.N., Srivastava, A.K. and Nayak, M.T., 2013. Antimicrobial property of extracts of Indian lichen against human pathogenic bacteria. Interdisciplinary Perspectives on Infectious Diseases, 10, 11551161.

Thippeswamy B., Naveenkumar K.J., Bodharthi J.G. and Shivaprasad S.R., 2011. Antimicrobial activity of ethanolic extract of Usnea longissima. Journal of Experimental Sciences, 2(12), 01-03.

Ünal, M.Ü., Uçan, F., Şener, A. and Dinçer, S., 2008. Research on antifungal and inhibitory effects of DL-limonene on some yeasts. Turkish Journal of Agricultural Forestry, 36, 576-582. 